\title{
Uji Hedonik Produk Foot Scrub Menggunakan Kulit Buah Naga Merah dan Air Rebusan Daun Pepaya
}

\author{
Desak Made Nita Pratiwi ${ }^{1)}$, Putu Pradnya Pramita Dewi ${ }^{1)}$, Putu Dessy Wilantari ${ }^{1)}$, Ni Kadek Cornelia \\ Ayu Trisna ${ }^{1}$, I Putu Yogi Astara Putra ${ }^{1)}$, Ni Putu Linda Laksmiani ${ }^{1)}$ \\ ${ }^{1}$ Jurusan Farmasi Fakultas Matematika dan Ilmu Pengetahuan Alam Universitas Udayana \\ Korespondensi: Desak Made Nita Pratiwi \\ Jurusan Farmasi Fakultas Matematika dan Ilmu Pengetahuan Alam Universitas Udayana \\ Jalan Kampus Unud-Jimbaran, Jimbaran-Bali, Indonesia 80364 Telp/Fax: 0361-703837 \\ Email: desaknita4@gmail.com
}

\begin{abstract}
ABSTRAK
Kulit buah naga merah memiliki kandungan alkaloid dan terpenoid yang memiliki aktivitas antibakteri Staphylococcus aureus dan Staphylococcus epidermidis. Bakteri ini dapat tumbuh di kulit khususnya pada bagian telapak kaki. Daun pepaya mengandung enzim papain yang dapat digunakan untuk mengangkat sel kulit mati. Maka dari itu, kulit buah naga merah dan daun pepaya dapat digunakan sebagai bahan baku dalam pembuatan foot scrub. Tujuan dari penelitian ini yaitu melakukan uji hedonik terhadap produk foot scrub untuk mengetahui tingkat kesukaan aroma, tekstur, dan kenyaman penggunaan pada produk foot scrub yang menggunakan variasi essential oil. Metode yang digunakan adalah metode analisis statistik deskriptif yang digunakan untuk menganalisa data dengan cara mendeskripsikan data yang telah terkumpul. Hasilnya menunjukkan bahwa hasil rata-rata produk foot scrub dengan 1 jenis essential oil yaitu chamomile oil lebih tinggi daripada produk foot scrub dengan campuran peppermint oil+chamomile oil dan produk foot scrub dengan campuran peppermint oil+chamomile oil+rose oil. Dari hasil tersebut dapat disimpulkan bahwa produk foot scrub dengan penggunaan chamomile oil saja lebih disukai dibandingkan dengan formulasi yang lainnya.
\end{abstract}

Keywords: Uji Hedonik, Kulit Buah Naga Merah, Air Rebusan Daun Pepaya, Foot Scrub

\section{PENDAHULUAN}

Indonesia merupakan negara dengan kondisi iklim tropis yang memiliki dua musim yaitu musim kemarau dan musim hujan. Hal tersebut berdampak pada kondisi fisik tubuh manusia yang harus beradaptasi dengan perubahan musim tersebut. Bagian tubuh yang paling sensitif terhadap perubahan musim adalah kulit. Kulit merupakan salah satu bagian panca indra yang sangat berfungsi bagi tubuh khususnya sebagai barier untuk mencegah mikroorganisme dan agen perusak lain masuk ke jaringan yang lebih dalam (Garna, 2001).

Kondisi iklim tropis menyebabkan kulit manusia menjadi salah satu organ yang diharuskan untuk beradaptasi. Apabila tidak dapat beradaptasi dengan baik maka akan muncul suatu masalah, salah satunya yaitu masalah pada kulit kaki yang lembab sehingga dapat dengan mudah menjadi pertumbuhan bakteri Staphylococcus aureus dan Staphylococcus epidermidis (Ryan, 1977). Pertumbuhan bakteri pada kulit kaki sering kali menyebabkan kaki merasa tidak nyaman karena kasar, keriput, pecah-pecah serta menyebabkan bau yang tidak sedap.

Kekayaan sumber daya alam dapat menunjang kelangsungan hidup manusia. Buah naga merah merupakan salah satu hasil sumber daya alam yang banyak ditemukan di wilayah Indonesia. Tetapi tidak banyak masyarakat yang mengetahui bahwa kulit buah naga merah juga memiliki manfaat yang baik bagi tubuh. Kulit buah naga merah (Hylocereus polyrhizus Britton\&Rose) memiliki kandungan alkaloid dan terpenoid yang memiliki aktivitas antibakteri Staphylococcus aureus dan Staphylococcus epidermidis (Amalia et al., 2014). Daun pepaya (Carica pepaya L.) mengandung enzim papain yang dapat digunakan untuk 
mengangkat sel kulit mati. Akibat dari sel kulit mati yaitu kaki kasar, keriput, dan pecahpecah (Margono, 2000). Maka dari itu, kulit buah naga merah dan daun pepaya dapat dimanfaatkan menjadi produk foot scrub yang berkhasiat sebagai pelembut dan penghilang bau kaki.

Foot scrub merupakan salah satu produk kosmetika yang biasa digunakan untuk menjaga kebersihan pada kaki. Produk foot scrub biasanya menggunakan bahan kimia, namun tidak jarang juga menggunakan bahanbahan alamiah. Produk foot scrub yang berkhasiat untuk melembutkan dan menghilangkan bau kaki memiliki aroma khas karena penggunaannya yang mengkhusus pada kaki.

Berdasarkan latar belakang tersebut diatas maka penulis tertarik melakukan eksperimen membuat foot scrub dengan menggunakan kulit buah naga merah dan air rebusan daun pepaya. Selain itu, pada penelitian ini akan dilakukan uji hedonik terhadap produk foot scrub untuk mengetahui tingkat kesukaan aroma, tekstur, dan kenyaman penggunaan pada produk foot scrub yang menggunakan variasi essential oil.

2. METODE

2.1 Waktu Penelitian
Pembuatan dan uji evaluasi produk foot scrub, serta pemasaran produk dilakukan dalam kurun waktu 5 bulan dari Februari 2017 hingga Juni 2017.

\subsection{Tempat Penelitian}

Proses pembuatan foot scrub dilakukan di salah satu rumah penulis yang bertempat di Pondok Nangka, Jalan Raya Kampus Bukit Jimbaran Universitas Udayana. Uji hedonik dilakukan di Jurusan Farmasi, Fakultas Matematika dan Ilmu Pengetahuan Alam Universitas Udayana.

\subsection{Metode Penelitian}

\subsubsection{Pembuatan Foot Scrub}

Basis (pembawa) foot scrub yang digunakan yaitu basis air dalam minyak. Pembuatan fase minyaknya dengan cara memanaskan asam stearat, adeps lanae, dan paraffin cair. Sedangkan fase airnya dibuat dengan cara mencampurkan air rebusan daun pepaya, methylparaben, dan trietanolamin. Kemudian, fase minyak dan fase air dicampurkan dalam kondisi panas pada suhu $70^{\circ} \mathrm{C}$ menggunakan mixer. Serbuk kulit buah naga dan tepung beras kasar dicampurkan ke dalam basis (pembawa) hingga homogen. Pencampuran terakhir yaitu ditambahkan essential oil.

Tabel 1. Formula Produk Foot Scrub

\begin{tabular}{|c|c|c|c|}
\hline Bahan & FI & FII & FIII \\
\hline Kulit Buah & $5 \%$ & $5 \%$ & $5 \%$ \\
\hline Naga Merah & & & \\
\hline $\begin{array}{l}\text { Tepung Beras } \\
\text { Kasar }\end{array}$ & $5 \%$ & $5 \%$ & $5 \%$ \\
\hline $\begin{array}{l}\text { Air Rebusan } \\
\text { Daun Pepaya }\end{array}$ & $55,55 \%$ & $55,55 \%$ & $55,55 \%$ \\
\hline Adeps Lanae & $3,03 \%$ & $3,03 \%$ & $3,03 \%$ \\
\hline Asam Stearat & $14,64 \%$ & $14,64 \%$ & $14,64 \%$ \\
\hline TEA & $1,51 \%$ & $1,51 \%$ & $1,51 \%$ \\
\hline Paraffin Cair & $25,25 \%$ & $25,25 \%$ & $25,25 \%$ \\
\hline Nipagin & Secukupnya & Secukupnya & Secukupnya \\
\hline Essential Oil & $\begin{array}{l}\text { Chamomile oil } \\
(0,0625 \%)\end{array}$ & $\begin{array}{l}\text { Peppermint oil } \\
(0,03125 \%)+\text { chamomile } \\
\text { oil }(0,03125 \%)\end{array}$ & $\begin{array}{l}\text { Peppermint oil } \\
(0,02083 \%)+\text { chamomile } \\
\text { oil }(0,02083 \%)+\text { rose oil } \\
(0,02083 \%)\end{array}$ \\
\hline
\end{tabular}

\subsubsection{Uji Hedonik}

Metode uji hedonik yang dilakukan oleh penulis adalah penelitian eksperimental.
Penelitian eksperimental ini merupakan penelitian yang dilakukan untuk memprediksi suatu fenomena, sehingga nantinya penulis 
dapat melakukan eksperimen pembuatan produk foot scrub dengan variasi essential oil. Penelitian eksperimental yang dilakukan yaitu one-shot case study. One-shot case study merupakan penelitian dimana terdapat suatu kelompok yang diberikan perlakuan dan selanjutnya dilakukan observasi untuk mendapatkan suatu hasil (Siregar, 2013). Sampel dari penelitian ini yaitu mahasiswa/I Jurusan Farmasi Fakultas Matematika dan Ilmu Pengetahuan Alam yang masih aktif berjumlah 200 orang.

Penelitian ini menggunakan metode kuantitatif dengan instrument penelitian yaitu berupa kuisioner. Dari data kuisioner ini akan dilakukan skala pengukuran. Dalam penelitian ini, skala pengukuran yang digunakan penulis yaitu enam skala hedonik yang merupakan skala hedonik seperti amat sangat suka, sangat suka, suka, agak suka, netral, dan tidak suka (Sofiah dan Achsyar, 2008; Laksmiani dkk., 2015).

Tabel 2. Skala Hedonik dengan Skala Numeriknya

\begin{tabular}{lc}
\hline \multicolumn{1}{c}{ Skala Hedonik } & $\begin{array}{c}\text { Skala } \\
\text { Numerik }\end{array}$ \\
\hline Amat Sangat Suka & 6 \\
Sangat Suka & 5
\end{tabular}

\begin{tabular}{ll} 
Suka & 4 \\
Agak Suka & 3 \\
Netral & 2 \\
Tidak Suka & 1 \\
\hline
\end{tabular}

Metode pengumpulan data yang digunakan dalam penelitian ini yaitu berupa data primer. Data primer didapatkan dari kuisioner kepada mahasiswa/I Jurusan Farmasi Fakultas Matematika dan Ilmu Pengetahuan Alam Universitas Udayana. Selain itu juga dapat berupa data sekunder yang merupakan data penunjang yang dapat berasal dari bukubuku atau pustaka lainnya yang terkait dengan penelitian. Teknik analisis data yang digunakan yaitu metode statistik deskriptif. Pada analisis deskriptif ini penyajian datanya dapat disajikan melalui tabel, grafik, diagram lingakaran atau batang, dan piktogram.

\section{HASIL}

Berdasarkan hasil uji hedonik terhadap produk foot scrub dengan variasi essential oil membuktikan bahwa produk foot scrub formula I lebih disukai dibandingkan dengan formula II dan III, hal ini dapat dibuktikan melalui grafik kesukaan dan rata-rata skor uji hedonik terhadap produk foot scrub.

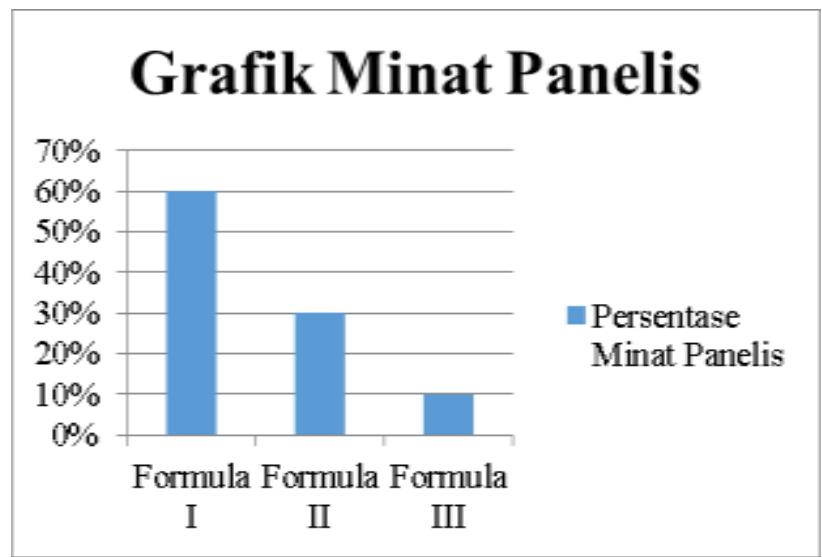

Gambar 1. Grafik Minat Konsumen Terhadap Produk Foot Scrub

Tabel 3. Rata-rata Skor Uji Hedonik Terhadap Produk Foot Scrub

\begin{tabular}{lccc}
\hline $\begin{array}{c}\text { Formula } \\
\text { Produk Foot } \\
\text { Scrub }\end{array}$ & Aroma & Tekstur & $\begin{array}{c}\text { Rata-rata Skor Uji Hedonik } \\
\text { Kengamanan } \\
\text { Penguanan }\end{array}$ \\
\hline Formula I & 5,75 & 5,75 & 5,75 \\
Formula II & 3,25 & 3,25 & 3,25 \\
Formula III & 2,75 & 2,75 & 2,75 \\
\hline
\end{tabular}




\section{PEMBAHASAN}

Foot scrub merupakan salah satu produk kosmetika yang sangat dijaga keamanan, kebersihan dan mutu dari produk. Produk foot scrub biasanya menggunakan bahan baku kimia diakibatkan karena masyarakat dominan mempercayai produk kosmetika yang berasal dari bahan-bahan kimia dan tidak memikirkan efek samping yang ditimbulkan. Kosmetik dari bahan alami terkadang menimbulkan efek samping atau ketidakcocokan, namun efek samping bahan kimia jauh lebih berbahaya dari bahan alami. Salah satu produk foot scrub menggunakan bahan-bahan alamiah yang berasal dari tumbuhan seperti kulit buah naga merah dan air rebusan daun pepaya.

Budidaya buah naga merah di Bali sudah berkembang sangat pesat, karena buah naga merah memiliki nilai jual yang tinggi. Panen buah naga merah dalam setiap tahunnya sekitar 30 ton per hektarnya. Masyarakat Bali yang mengkonsumsi buah naga merah secara berkala menyebabkan terjadinya penumpukan limbah kulit buah naga merah. Tidak semua penduduk Bali mengetahui manfaat dan penggunaan dari kulit buah naga merah. Sebagian kecil masyarakat Bali memanfaatkan kulit buah naga merah sebagai tumbuhan yang mampu memperlancar peredaran darah dan menghaluskan kulit. Di bali juga hampir seluruh masyarakatnya membudidayakan atau mengembangkan pohon pepaya. Bagian daging dan daun buah pepaya sering digunakan sebagai olahan makanan. Konsumsi daging buah pepaya sekitar 50-60 ton per hari. Konsumsi daun pepaya sangat sedikit dibandingkan dagingnya, karena daun pepaya memiliki rasa yang pahit bila dikonsumsi.

Maka dari itu, bahan-bahan alami yang sangat jarang dimanfaatkan dapat dijadikan suatu produk yang bermanfaat menjadi produk foot scrub ini. Pembuatan produk foot scrub ini disamping menggunakan bahan baku alami terdapat juga bahan-bahan tambahan seperti beras, adeps lanae, asam stearat, TEA, paraffin cair, nipagin dan essential oil. Pembuatan foot scrub sangat mudah untuk dilakukan, pengerjaan sederhana dan tidak menghabiskan waktu yang lama dalam pengerjaan. Untuk menarik minat konsumen, dalam produk foot scrub ini ditambahkan essential oil yang dapat memberikan aroma yang segar bagi pemakainya.

Produk foot scrub yang paling disukai dari segi aroma, tekstur, dan kenyamanan penggunaan yaitu formula I dengan penggunaan 1 jenis essential oil yaitu chamomile oil dengan rata-rata skor 5,75. Formula ini memiliki aroma yang menyegarkan dengan tekstur yang lembut dan kandungan essential oil yang hanya 1 jenis sehingga tidak mempengaruhi basis scrub dan membuat produk ini tidak berminyak sehingga sangat nyaman digunakan. Pada formula II peminatnya tidak lebih banyak dibandingkan formula I dengan skor rata-rata uji hedonik sebesar 3,25. Formula II ini menggunakan 2 jenis essential oil gabungan antara peppermint oil dan chamomile oil. Akibat pencamuran 2 jenis essential oil ini menyebabkan tekstur yang sedikit berminyak, saat diaplikasikan terasa sedikit panas akibat penggunaan peppermint oil, namun untuk aroma sangat disukai oleh konsumen karena pencampuran 2 jenis essential oil ini memberikan aroma yang sejuk dan menyegarkan. Sedangkan, formula III dengan rata-rata skor uji hedonik sebesar 2,75. Penggunaan 3 jenis essential oil pada formula III yaitu pencampuran peppermint oil, chamomile oil, dan rose oil memberikan tekstur yang sangat berminyak sehingga tidak nyaman untuk digunakan, selain itu akibat penggunaan peppermint oil terasa sedikit panas saat diaplikasikan ke kulit kaki. Namun, untuk aroma tidak menjadi masalah, hanya saja penyampuran 3 jenis essential oil memberikan aroma yang sangat menyengat. Harapannya dengan melalukan eksperimen pembuatan foot scrub yang berasal dari bahan baku alami yaitu kulit buah naga merah dan air rebusan daun pepaya dapat menjadi pedoman untuk membuka usaha produk kosmetika yang diproduksi rumahan dan membuka lapangan pekerjaan baru.

\section{KESIMPULAN}

Hasil uji hedonik terhadap produk foot scrub dengan variasi essential oil menunjukkan bahwa formula I dengan penggunaan 1 jenis essential oil yaitu chamomile oil lebih disukai oleh konsumen melihat dari aroma, tekstur, dan kenyamanan penggunaan. Dari pembuatan produk foot 
scrub dengan berbagai formula ini terbukti dengan penggunaan 1 jenis essential oil sudah cukup baik dibandingkan pencampuran essential oil.

\section{UCAPAN TERIMAKASIH}

Penulis menghaturkan terima kasih kepada Direktorat Pendidikan Tinggi Kementrian Pendidikan dan Kebudayaan Republik Indonesia dan Rektor Universitas Udayana melalui Jurusan Farmasi Fakultas Matematika dan Ilmu Pengetahuan Alam Universitas Udayana yang telah memfasilitasi dan mendanai penelitian dan kewirausahaan ini. Mahasiswa/I Jurusan Farmasi Fakultas Matematika dan Ilmu Pengetahuan Alam Universitas Udayana yang masih aktif yang bersedia menjadi panelis dalam penelitian ini.

\section{DAFTAR PUSTAKA}

Amalia, S., S. Wahdaningsih, dan E. Kartika. 2014. Uji Aktivitas Antibakteri Fraksi $n$-Heksan Kulit Buah Naga Merah (Hylocereus polyrhizus Britton\&Rose) Terhadap Bakteri Staphylococcus

Garna, H. 2001. Patofisiologi Infeksi Bakteri pada Kulit. Sari Pediatri 2(4): 205209.

Laksmiani, N. P. L., N. K. Warditiani dan C. I. S. Arisanti. 2015. Pelatian Pemanfaatan Garam Krosok Menjadi Garam Spa (Bath Salt dan Foot Salt) di Desa Jimbaran Kuta Slatan Badung Bali. Udayana Mengabdi 14(2): 9194.

Margono, T. 2000. Pepaya. Jakarta: Subdid Teknologi Pengolahan Pepaya.

Ryan, J. L. 1977. Bacterial diseases. Edisi ke9. London: Prentice-Hall intern Inc, hal. 684-93.

Siregar, S. 2013. Statistik Parametrik Untuk Penelitian Kuantitatif. (Cetakan ke-1). Jakarta: Bumi Aksara

Sofiah, B. D., dan Achyar, T. S. 2008. Buku Ajar Kuliah Penilaian Indra. (Cetakan ke-1). Jatinagor: Universitas Padjadjaran. aureus ATCC 25923. Traditional

Medicine Journal 19(2): 89-94. 